\title{
PENGGUNAAN REDUPLIKASI DAN KOMPOSISI PADA MAKALAH MAHASISWA MALAYSIA UIN SUNAN AMPEL SURABAYA
}

\author{
Ira Eko Retnosari \\ Fakultas Keguruan dan Ilmu Pendidikan \\ Universitas PGRI Adi Buana Surabaya \\ ira_eko_80@yahoo.com
}

\begin{abstract}
This article aims to describe the mastery of reduplication and composition on Malaysian student paper UIN Sunan Ampel Surabaya. The approach used in this article is descriptive qualitative with data collection using documentation method. The data collection procedures in this article were (1) the collection of papers, (2) photocopies of papers, (3) reading of papers, (4) tagging with highlighter, (5) classification, and (6) encoding. Analyzing data in this research using descriptive method. The stages used in analyzing data are (1) data collection, (2) data classification, and (3) explanation. The data of this article are the words in Malaysian student paper UIN Sunan Ampel Surabaya and the data source of this article is a student paper Malaysian UIN Sunan Ampel Surabaya. The results of this article's analysis found (1) full reduplication, (2) reduplication in combination with affix affixing, and (3) composition.
\end{abstract}

Keywords: reduplication, composition, Malaysian student papers

\section{PENDAHULUAN}

Globalisasi dapat menembus batasbatas budaya melalui jangkauan luas perjalanan udara, komunikasi yang semakin luas, dan meningkatnya masyarakat dunia yang bepergian ke berbagai negara (Muslich, 2012:5). Hal tersebut tidak hanya terjadi pada sektor pariwisata, tetapi juga merambah ke berbagai sektor, seperti pendidikan.

Pelajar asing yang ingin melanjutkan studi ke luar negeri secara tidak langsung dituntut untuk menguasai bahasa asing tersebut. Tuntutan penguasaan bahasa negara, khususnya yang menjadi bahasa pengantar pembelajaran merupakan wujud konsekuensi logis ketika pelajar memutuskan menuntut ilmu di negara lain. Permasalahan akan muncul saat pelajar asing tersebut kurang memahami bahasa negara tempat pelajar tersebut melanjutkan studi. Misalnya, pelajar asing yang melanjutkan studi strata satu di negara lain.
Pelajar asing yang berstatus mahasiswa sangat erat dengan kegiatan menulis. Mahasiswa diwajibkan menulis dalam perkuliahan. Di Indonesia, ketidakmampuan menggunakan bahasa Indonesia salah satunya dialami mahasiswa (Chaer, 2013:29). Ia menambahkan penyebab warga Indonesia tidak mampu secara maksimal berbahasa dengan baik dan benar adalah bahasa Indonesia bukan bahasa ibu dan sikap negatif terhadap bahasa Indonesia (Chaer,2013:32). Ada mahasiswa sulit memahami kaidah bahasa Indonesia. Hal tersebut terlihat dengan banyaknya pendampingan dan pembinaan bahasa, khususnya kegiatan menulis. Kenyataan inilah yang menjadi alasan bahwa perlunya perhatian khusus terhadap kompetensi menulis mahasiswa, khususnya mahasiswa asing.

Kompetensi menulis harus dimiliki semua mahasiswa. Sebelum menulis, mahasiswa harus memunyai kosakata yang cukup untuk menuangkan idenya. Dalam artikel ini, dibahas reduplikasi dan komposisi. 
Reduplikasi adalah pengulangan bentuk, baik seluruhnya maupun sebagian, baik dengan variasi fonem maupun tidak, sedangkan komposisi adalah proses penggabungan dasar dengan dasar (biasanya, berbentuk akar atau bentuk berimbuhan) untuk mewadahi "konsep" yang belum tertampung pada sebuah kata. Pemilihan topik tersebut karena mahasiswa asing sebelum membuat kalimat diharapkan memahami kaidah penulisan kata.

\section{METODE PENELITIAN}

Penelitian ini bertujuan mendeskripsikan penguasaan reduplikasi dan komposisi pada makalah mahasiswa UIN Sunan Ampel Surabaya. Berdasarkan tujuan tersebut, penelitian ini merupakan penelitian kualitatif, yakni penelitian yang tidak mengadakan perhitungan atau angka (Moleong, 2001:2).

Sumber data penelitian ini adalah makalah mahasiswa MalaysiaUIN Sunan Ampel Surabaya. Data penelitian ini adalah kata-kata dalam makalah mahasiswa Malaysia UIN Sunan Ampel Surabaya.

Pengumpulan data dalam penelitian ini dilakukan melalui metode dokumentasi. Metode ini dilakukan dengan cara mendokumentasikan lima makalah. Prosedur pengumpulan data dalam penelitian ini adalah (1) pengumpulan makalah, (2) pemfotokopian makalah, (3) pembacaan makalah, (4) penandaan dengan stabilo, dan (5) pengklasifikasian.

Penganalisisan data dalam penelitian ini menggunakan metode deskriptif. Artinya, peneliti hanya mendeskripsikan reduplikasi dan komposisi. Adapun tahap-tahap yang digunakan dalam penganalisisan data adalah (1) pengumpulan data, (2) pengklasifikasian data, dan (3) pengeksplanasian.

\section{HASIL DAN PEMBAHASAN}

Reduplikasi adalah proses pengulangan pada bentuk dasar untuk mendapatkan makna tertentu (Chaer, 2008:78). Ia menambahkan bahwa jenis-jenis reduplikasi antara lain (1) reduplikasi penuh, (2) reduplikasi sebagian, (3) reduplikasi dengan perubahan bunyi.Menurut Ramlan (2009:63), reduplikasi adalah pengulangan satuan gramatik, baik seluruhnya maupun sebagian, baik dengan variasi fonem ataupun tidak.

Muslich (1990:48) berpendapat bahwa proses pengulangan merupakan peristiwa pembentukan kata dengan mengulang bentuk dasar, baik seluruhnya maupun sebagian, baik bervariasi fonem maupun tidak, baik berkombinasi dengan afiks maupun tidak.Menurut Kridalaksana (2008:88), reduplikasi adalah proses dan hasil pengulangan satuan bahasa sebagai alat fonologis atau gramatikal, seperti rumah-rumah, bolak-balik, tetamu.

Menurut Keraf (1991), reduplikasi dapat ditinjau dari segi bentuk, makna, dan fungsi reduplikasi.

\subsection{Bentuk-bentuk Reduplikasi}

Ramlan (2009:69-75) mengatakan bahwa berdasarkan cara mengulang bentuk dasarnya, pengulangan dapat digolongkan menjadi empat golongan yaitu:

1. Pengulangan seluruh

Pengulangan seluruh adalah pengulangan seluruh bentuk dasar, tanpa perubahan fonem dan tidak berkombinasi dengan proses pembubuhan afiks (Ramlan, 2009:69). Misalnya:

$\begin{array}{ll}\text { meja } \rightarrow & \text { meja-meja } \\ \text { pertemuan } \rightarrow & \text { pertemuan-pertemuan } \\ \text { keuntungan } \rightarrow & \text { keuntungan- }\end{array}$

keuntungan

2. Pengulangan sebagian

Pengulangan sebagian adalah pengulangan sebagian dari bentuk dasarnya (Ramlan, 2009:70). Pada pengulangan sebagian, bentuk dasar tidak diulang seluruhnya. Hampir semua bentuk dasar 
pengulangan golongan ini berupa bentuk kompleks. Misalnya:

$$
\begin{aligned}
& \text { mengangkat } \quad \rightarrow \text { mengangkat-angkat } \\
& \text { dicincang } \rightarrow \text { dicincang-cincang } \\
& \text { berlari } \rightarrow \text { berlari-lari } \\
& \text { tertusuk } \rightarrow \text { tertusuk-tusuk } \\
& \text { bermesraan } \quad \rightarrow \text { bermesra-mesraan } \\
& \text { ketujuh } \rightarrow \text { ketujuh-tujuh }
\end{aligned}
$$

3. Reduplikasi yang Berkombinasi dengan Proses Pembubuhan Afiks

Dalam golongan ini, bentuk dasar diulang seluruhnya dan berkombinasi dengan proses pembubuhan afiks. Maksudnya, pengulangan itu terjadi bersama-sama dengan proses pembubuhan afiks dan bersama-sama pula mendukung fungsi. Misalnya kata ulang kereta-keretaan. Berdasarkan petunjuk penentuan bentuk dasar, dapat ditentukan bahwa bentuk dasar bagi kata ulang keretakeretaan adalah kereta dan bukannya keretaan mengingat satuan keretaan tidak terdapat dalam pemakaian bahasa.

4. Pengulangan dengan perubahan fonem

Kata ulang yang pengulangannya termasuk golongan sebenar-benarnya sangat sedikit. Disamping bolak-balik terdapat kata kebalikan, sebaliknya, dibalik, membalik. Dari perbandingan itu, dapat disimpulkan bahwa kata bolak-balik dibentuk dari bentuk dasar balik yang diulang seharusnya dengan perubahan fonem, ialah dari /a/ menjadi /o/, dan dari /i/ menjadi /a/.

Sejalan dengan pendapat Ramlan, Muslich (2010:52) menyebutkan reduplikasi terdapat empat macam:

1. Pengulangan seluruh, yaitu pengulangan bentuk dasar secara keseluruhan, tanpa berkombinasi dengan pembubuhan afiks dan tanpa perubahan fonem.

Contoh: batu $\rightarrow$ batu-batu, sembilan $\rightarrow$ sembilan, persatuan $\rightarrow$ persatuanpersatuan
2. Pengulangan sebagian, yaitu pengulangan bentuk dasar secara sebagian, tanpa perubahan fonem.

Contoh: $\{$ me- $\}+$ nulis $\rightarrow$ menulis-nulis $\{$ ber- $\}+$ kata $\rightarrow$ berkata-kata $\quad\{$ se- $\}+$ akan $\rightarrow$ seakan-akan

3.Pengulangan yang berkombinasi dengan pembubuhan afiks, yaitu pengulangan bentuk dasar disertai dengan penambahan afiks secara bersamasama atau serentak dan bersama-sama pula mendukung satu arti.

Contoh: rumah $+\{$-an $\} \rightarrow$ rumahrumahan $\{$ se- $\}+$ baik $+\{$-nya $\} \rightarrow$ sebaik-baiknya $\{\mathrm{ke}-\}+$ hijau $+\{$-an $\}$ $\rightarrow$ kehijau-hijauan

4.Pengulangan dengan perubahan fonem, yaitu pengulangan bentuk dasar dengan disertai perubahan fonem.

Contoh: ramah-tamah $\rightarrow$ (bentuk dasar ramah) sayur-mayur $\rightarrow$ (bentuk dasar sayur) serba-serbi $\rightarrow$ (bentuk dasar serba)

Sementara itu, Kridalaksana (2007: 89) menyebutkan terdapat tiga macam reduplikasi, yakni sebagai berikut.

1. Reduplikasi fonologis, di dalam reduplikasi fonologis tidak terjadi perubahan makna karena pengulangannya hanya bersifat fonologis. Artinya, tidak ada pengulangan leksem. Contoh pada kata dada, pipi, kuku, paru-paru. Contoh tersebut merupakan bentuk reduplikasi fonologis, karena bentuk-bentuk tersebut bukan berasal dari leksem *da, *pi, *ku, dan * paru.

2. Reduplikasi morfemis, di dalam reduplikasi morfemis terjadi perubahan makna gramatikal atas leksem yang diulang. Contoh pada kata mengangkatangkat, berbisik-bisik, berpindah-pindah, tergila-gila.

3. Reduplikasi sintaktis adalah proses yang terjadi atas leksem yang menghasilkan satuan yang berstatus klausa, jadi berada 
di luar cakupan morfologi. Contoh pada kata jauh-jauh, asam-asam.

Pembagian macam-macam reduplikasi terdapat persamaan antara teori Ramlan (2009:69) dengan teori Muslich (2010:52), yakni pengulangan seluruh, pengulangan sebagian, pengulangan yang berkombinasi dengan pembubuhan afiks, dan pengulangan dengan perubahan fonem. Dalam artikel ini, ditemukan reduplikasi penuh dan reduplikasi yang berkombinasi dengan pembubuhan afiks.

\subsection{Makna Reduplikasi}

Ramlan (2009:175) mengatakan bahwa proses pengulangan baik yang penuh maupun sebagian ada yang berfungsi mengubah golongan kata ada pula yang tidak. Pada kata ulang karang-mengarang, cetak-mencetak, potong-memotong, jilid-menjilid; berfungsi sebagai pembentuk kata nominal dari kata kerja. Pada kata ulang secepat-cepatnya, serajin-rajinnya, setinggi-tingginya, sekuatkuatnya berfungsi sebagai keterangan dari kata sifat. Tetapi pada kata ulang binatang-binatang, rumah-rumah, pembangunan-pembangunan, kuda-kudaan, anak-anakan, surat-menyurat, cepat-cepat, kecil-kecil, proses pengulangan tidak mengubah golongan kata.

Proses pengulangan menyatakan beberapa makna.

1. Menyatakan makna 'banyak'

Bandingkan kata rumah dengan kata rumah-rumah dalam kalimat di bawah ini:

Gedung itu sangat megah.

Gedung-gedung itu sangat megah.

Kata gedung dalam kalimat Gedung itu sangat megah menyatakan 'sebuah gedung', sedangkan kata gedung-gedung dalam kalimat Gedung-gedung itu sangat megah menyatakan banyak gedung. Demikian juga:

hewan-hewan: 'banyak hewan'

keuntungan-keuntungan: 'banyak keuntungan'

2. Menyatakan makna 'banyak'
Berbeda dengan makna yang tersebut di atas, di sini makna 'banyak' itu tidak berhubungan dengan bentuk dasar, tetapi berhubungan dengan kata yang 'diterangkan'. Kata yang 'diterangkan' itu pada tataran fase menduduki fungsi sebagai unsur pusat, misalnya kata rumah dalam frase rumah besarbesar dan pada tataran klausa menduduki fungsi sebagai subjek. Misalnya, kata rumah dalam klausa rumah itu besar-besar. Jelasnya, pengulangan pada kata besar-besar itu menyatakan makna 'banyak' bagi kata yang diterangkan, yakni kata rumah.

3. Menyatakan makna 'tak bersyarat'

Cermati kalimat di bawah ini!

Jika tidak hujan, saya akan datang.

Klausa saya akan datang memunyai syarat, yaitu apabila tidak hujan. Dengan demikian, dapat dikatakan bahwa kata jika dalam kalimat itu menyatakan makna 'syarat' sebaliknya dalam kalimat:

Meskipun hujan, saya akan datang.

Klausa saya akan datang tidak bersyarat. Demikianlah, kata meskipun menyatakan makna 'tak bersyarat'.

4. Menyatakan makna 'yang menyerupai' apa yang tersebut pada bentuk dasar.

Dalam hal ini, proses pengulangan berkombinasi dengan proses pembubuhan afiks -an. Misalnya:

mobil: 'mobil-mobilan'

ayam: 'ayam-ayaman'

5. Menyatakan bahwa perbuatan yang tersebut pada bentuk dasar dilakukan berulang-ulang. Misalnya:

bergerak-gerak: 'bergerak berkali-kali' melirik-lirik: 'melirik berkali-kali'

6. Menyatakan bahwa perbuatan yang tersebut pada bentuk dasarnya dilakukan dengan enaknya, dengan santainya, atau dengan senangnya.

Cermati kata $d u d u k-d u d u k$ dalam kalimat: 
Seluruh anggota keluarga duduk-duduk di teras muka.

Pengulangan pada kata duduk-duduk dalam kalimat itu menyatakan bahwa 'perbuatan itu dilakukan dengan enaknya, dengan santainya, dan dengan senangnya'.

7. Menyatakan bahwa pembuatan yang tersebut pada bentuk dasar itu dilakukan oleh dua pihak saling mengenai.

Dengan kata lain, pengulangan itu menyatakan makna 'saling'. Misalnya: pandang-memandang: 'saling memandang' sapa-menyapa: 'saling menyapa'

8. Menyatakan 'hal-hal yang berhubungan dengan pekerjaan yang tersebut pada bentuk dasar'. Misalnya:

sulam-menyulam: 'hal yang berhubungan dengan pekerjaan menyulam'

tulis-menulis: 'hal yang berhubungan dengan pekerjaan menulis'

9. Menyatakan makna 'agak'

Dalam kalimat:

Celananya kehitam-hitaman.

Sebenarnya celana itu tidak hitam benar, tetapi hanya tampak agak atau sedikit hitam. Demikianlah, pengulangan yang berkombinasi dengan pembubuhan afiks $k e$ an pada kata kehijau-hijauan menyatakan makna 'agak' atau 'sedikit' .

10. Menyatakan makna 'tingkat yang paling tinggi yang dapat dicapai' dalam hal ini pengulangan berkombinasi dengan proses pembubuhan afiks se-nya. Misalnya:

sepandai-pandainya: "tingkat pandai yang paling tinggi yang dapat dicapai'

sesabar-sabarnya: 'tingkat sabar yang paling tinggi yang dapat dicapai'

11. Selain makna-makna yang tersebut di atas, terdapat juga proses pengulangan yang sebenarnya tidak mengubah bentuk dasarnya. Akan tetapi, hanya 'menyatakan intsnsitas perasaan'. Misalnya, kata mengharapkan dengan mengharapharapkan, membedakan dengan membeda- bedakan, sekenyangnya dengan sekenyang-kenyangnya, berlarian dengan berlari-larian.

Hasil analisis data reduplikasi dijelaskan seperti di bawah ini.

\section{A. Reduplikasi Penuh}

Berdasarkan penjelasan data di atas, data yang mengandung reduplikasi penuh sebagai berikut.

(1) ... kesempurnaan pembuatan makalah-makalah selanjutnya. (M.1/KP/P4/K1)

(2) Tanda baca merupakan tanda-tanda yang digunakan di dalam bahasa tulis .... (M.2/B.I/P1/K1)

(3) Kalimat-kalimat akan lebih tersusun rapi. (M.2/B.I/P2/K6)

(4) $\ldots$ diletakkan di tempat-tempat tertentu dalam kalimat berdasarkan tujuan dan kecocokannya. (M.2/B.I/P3/K2)

(5) Ia diletakkan di tempat-tampat tertentu dalam ....(M.3/B.I/P2/K2)

(6) ... kepada pihak-pihak yang .... (M.3/KP/P3/K1)

(7) ... kepada pihak-pihak yang .... (M.5/KP/P3/K1)

(8) ... dalam penggunaan macam-macam huruf, .... (M.3/B.I/P1/K4)

(9) Pengertian dan ciri-ciri masyarakat modern. (M.5/B.IV/P3/K1)

(10) ... menyatakan fungsi-fungsi tanda baca .... (M.5/B.I/P3/K1)

(11) ... hal-hal yang disebut dalam kalimat .... (M.5/B.I/P1/K1)

(12)Lebih-lebih lagi mahasiswa seperti .... (M.2/B.V/P3/K1)

(13) Pedagang-pedagang Melayu yang berkeliling di Indonesia .... (M.1/B.I/P1/K6)

(14) Kesalahan-kesalahan yang terdapat dalam makalah .... (M.5/B.IV/P1/K1)

Data (1-13) mengandung proses reduplikasi utuh, yaitu pada kata makalah- 
makalah,tanda-tanda, kalimat-kalimat, tempattempat, pihak-pihak, ciri-ciri, fungsi-fungsi, hal-hal, lebih-lebih, macam-macam, pedagangpedagang, dan kesalahan-kesalahan. Pada data (1), kata makalah-makalah terbentuk dari kata dasar makalah yang mengalami reduplikasi menjadi makalah-makalah. Kata makalahmakalah bermakna 'banyak makalah'. Data (2) mengandung reduplikasi tanda-tanda. Kata ulang tersebut terbentuk dari kata dasar tanda yang mengalami reduplikasi menjadi tandatanda. Kata tanda-tandabermakna 'bermacammacam tanda'.

Pada data (3), terdapat kata kalimatkalimat yang terbentuk dari kata dasar kalimat yang mengalami reduplikasi menjadi kalimatkalimat. Kata ulang tersebut berarti 'bermacammacam kalimat'. Data (4-5) mengandung kata tempat-tempat. Kata ulang tersebut terbentuk dari kata dasar tempat yang mengalami reduplikasi menjadi tempat-tempat yang bermakna 'banyak tempat'.

Data (6-7) mengandung kata pihakpihak. Kata ulang tersebut terbentuk dari kata dasar pihak yang mengalami reduplikasi menjadi pihak-pihak yang bermakna 'banyak pihak'. Pada data (8), kata macam-macam terbentuk dari katadasar macam yang mengalami reduplikasi menjadi macam-macam. Kata ulang tersebut bermakna 'bermacammacam jenis'.

Pada data (9), kata ciri-ciri terbentuk dari katadasarciriyang mengalami reduplikasi menjadi ciri-ciri. Kata ulang tersebut bermakna 'banyak ciri'. Data (10) mengandung kata ulang fungsi-fungsi. Kata tersebut terbentuk dari kata dasar fungsi yang mengalami reduplikasi menjadi fungsi-fungsi. Kata ulang fungsi-fungsi bermakna 'banyak fungsi'. Pada data (11), terdapat kata ulang hal-hal. Kata ulang tersebut terbentuk dari kata dasar hal yang mengalami reduplikasi menjadi hal-hal. Kata ulang tersebut berarti 'banyak hal'. Data (12) mengandung kata ulang lebih-lebih. Kata ulang tersebut terbentuk dari kata lebih yang mengalami reduplikasi menjadi lebih-lebih. Kata ulang lebih-lebih bermakna 'intensitas'.

Data (13-14) mengandung kata ulang pedagang-pedagang dan kesalahan-kesalahan. Sebenarnya, kedua kata ulang tersebut terbentuk dari kata dasar dagang dan salah. Kata dasar dagang mendapatkan sufiks pemenjadi pedagang,sedangkan kata dasar salah mendapatkan konfiks ke-an menjadi kesalahan. Karena yang diulang berupa kata beafiks utuh, kata pedagang-pedagang dan kesalahankesalahan termasuk dalam reduplikasi penuh. Kedua kata tersebut bermakna 'banyak' .

\section{B. Reduplikasi yang Berkombinasi dengan Proses Pembubuhan Afiks}

Data yang mengandung reduplikasi yang berkombinasi dengan proses pembubuhan afiks seperti di bawah ini.

(1) Penulis menyampaikan terima kasih yang sebesar-besarnya kepada .... (M.1/KP/P3/K1)

(2) ... ucapan terima kasih yang sebesarbesarnya kepada .... (M.3/KP/P3/K1)

(3) ... terima kasih yang sebesar-besarnya kepada semua pihak .... (M.4/KP/P2/K2)

(4) ... terima kasih yang sebesar-besarnya kepada .... (M.5/KP/P3/K1)

(5) ... penghargaan yang setinggi-tingginya kepada .... (M.3/KP/P1/K1)

(6) ... penghargaan yang setinggi-tingginya kepada .... (M.5/KP/P3/K2)

Pada data (1-6), terdapat proses reduplikasi dengan berkonfiks se-nya dan yang direduplikasikan hanya akarnya saja, yaitu pada kata sebesar-besarnya dan setinggi-tingginya. Kata sebesar-besarnya memiliki kata dasar besar dengan konfiks se-nya menjadi sebesarnya. Kemudian, direduplikasikan hanya akarnya saja menjadi sebesar-besarnya yang memiliki arti 'paling atau sangat'. Begitu juga 
dengan kata setinggi-tingginya,kata setinggitingginya memiliki kata dasar tinggi dengan konfiks se-nya menjadi setingginya. Kemudian, direduplikasikan hanya akarnya saja menjadi setinggi-tingginya yang memiliki arti "tingkat yang paling tinggi yang dapat dicapai”.

\subsection{Komposisi}

Komposisi adalah proses penggabungan dasar dengan dasar (biasanya, berbentuk akar atau bentuk berimbuhan) untuk mewadahi "konsep" yang belum tertampung pada sebuah kata (Chaer, 2008:209). Menurut Kridalaksana (2007:104), komposisi adalah proses penggabungan dua leksem atau lebih yang membentuk kata. Sementara itu, Muslich (2010: 57) menyebutkan komposisi adalah peristiwa bergabungnya dua morfem dasar atau lebih secara padu dan menimbulkan arti yang relatif baru. Sejalan dengan Muslich, Chaer (2008:209) menyatakan komposisi adalah proses penggabungan dasar dengan dasar (biasanya berupa akar maupun bentuk berimbuhan) untuk mewadahi suatu 'konsep' yang belum tertampung dalam sebuah kata.

Dalam penggabungan kata, beberapa hal yang perlu diperhatikan penulisannya. (1) Gabungan kata yang lazim disebut kata majemuk, termasuk istilah khusus, bagianbagiannya umumnya ditulis terpisah. (2) Gabungan kata, termasuk istilah khusus, yang mungkin menimbulkan salah baca, dapat diberi tanda hubung untuk menegaskan pertalian di antara unsur yang bersangkutan. (3) Gabungan kata yang dianggap sebagai satu kesatuan ditulis serangkai (Sugihastuti, 2007:38).

Ramlan (2009:76) berpendapat bahwa kata majemuk adalah kata yang terdiri atas dua kata sebagai unsurnya. Ia menambahkan ciriciri kata majemuk adalah (1) salah satu unsurnya berupa pokok kata, seperti kolam renang, pasukan tempur, tenaga kerja, (2) unsur-unsurnya tidak mungkin dipisahkan atau tidak mungkin diubah strukturnya, misalnya mata pelajaran, daun pintu, pejabat tinggi.

Tujuan utama membentuk komposisi adalah menampung atau mewadahi konsepkonsep yang ada dalam bentuk kehidupan, tetapi belum ada wadahnya dalam bentuk sebuah kata. Berdasarkan usaha menampung konsep-konsep ini, dapat dibedakan adanya lima macam komposisi (Chaer, 2008:212-215).

a) Komposisi yang menampung konsepkonsep yang digabungkan sederajat sehingga membentuk komposisi yang koordinatif. Misalnya, penggabungan dasar makan dan dasar minum menjadi komposisi makan minum; penggabungan dasar kaya dan dasar miskin menjadi komposisi kaya miskin; penggabungan dasar ayam dan dasar itik menjadi komposisi ayam itik.

b) Komposisi yang menampung konsepkonsep yang digabungkan tidak sederajat sehingga melahirkan komposisi subordinatif. Dalam komposisi ini, unsur pertama merupakan unsur utama dan unsur kedua merupakan unsur penjelas. Misalnya, dasar sate sebagai unsur utama digabung dengan dasar ayam sebagai unsur penjelas menjadi komposisi sate ayam yang bermakna gramatikal 'sate yang berbahan daging ayam'.

c) Komposisi yang menghasilkan istilah, yakni yang bermakna sudah pasti, sudah tertentu, meskipun bebas dari konteks kalimatnya karena sebagian istilah digunakan dalam bidang ilmu atau kegiatan tertentu. Makna istilah dalam komposisi ini tidak ditentukan oleh hubungan kedua unsurnya, tetapi juga ditentukan oleh keseluruhannya.

Beberapa istilah dalam bentuk komposisi:

a. istilah olahraga:

- tolak peluru

- terjun payung

- terbang layang 
b. istilah linguistik:

- morfem bebas

- klausa verbal

c. istilah politik

- hak pilih

- sidang paripurna

d. istilah pendidikan

- buku ajar

- model pembelajaran

e. istilah agama (Islam)

- zakat fitrah

- ibadah haji

d) Komposisi pembentuk idiom, yakni penggabungan dasar dengan dasar yang menghasilkan makna idiomatik, yaitu makna yang tidak dapat diprediksi secara leksikal maupun gramatikal. Misalnya, penggabungan meja dengan dasar hijau yang menghasilkan komposisi meja hijau dengan makna 'pengadilan'.

e) Komposisi yang menghasilkan nama, yakni yang mengacu pada sebuah maujud dalam dunia nyata. Misalnya, Griya Matraman, Stasiun Gambir, dan Selat Sunda.

komposisi.

Berikut ini data yang mengandung

(1) ... Analisis Penggunaan Tanda Baca dalam makalah ilmu dakwah Pelajar Jurusan .... (M.1/KP/P1/K1)

(2) ... proses penyiapan karya ilmiah ini dan secara tidak langsung .... (M.1/KP/P2/K2)

(3) ... dalam menyelesaikan karya tulis ini. (M.3/KP/P3/K2)

(4) ... selaku dosen pembimbingmata kuliah Bahasa Indonesia yang senantiasa memberikan tunjuk ajar. (M.1/KP/P3/K1)

(5) ... kepada orang tua yang senantiasa membimbing dan mendoakan dalam segala hal walaupun dalam jarak yang jauh. (M.1/KP/P3/K2)
(6) ... ingin menyampaikan ucapan terima kasih kepada beberapa pihak .... (M.2/KP/P2/K1)

(7) ... ucapan terima kasih yang sebesarbesarnya .... (M.3/KP/P3/K1)

(8) ... rasa hormat dan terima kasih yang .... (M.4/KP/P2/K2)

(9) ... penulis menyampaikan ucapan terima kasih yang .... (M.5/KP/P3/K1)

(10) ... untuk meningkatkan ilmu pengetahuan mengenai (M.3/B.I/P2/K2)

(11) Pengertian dan ciri-ciri masyarakat modern. (M.5/B.IV/P3/K1)

Pada data (1), terdapat proses komposisi, yaitu tanda baca dan ilmu dakwah. Komposisi kata tanda baca pada data (1) merupakan gabungan dari kata tanda dan baca. Komposisi tanda baca berarti 'tanda yang digunakan untuk membaca'. Sementara itu,komposisi kata ilmu dakwah merupakan gabungan dari kata ilmu dan dakwah. Komposisi ilmu dakwah bermakna 'ilmu yang berhubungan dengan dakwah'. Komposisi kata karya ilmiah pada data (2) berarti 'karya yang dapat dibuktikan dengan metode ilmiah', dan komposisi kata karya tulis pada data (3)bermakna 'karya yang berupa sebuah tulisan'.

Data (4) mengandung proses komposisi dosen pembimbing, mata kuliah, dan tunjuk ajar. Kata dosen pembimbing merupakan komposisi yang menghasilkan istilah dan maknanya sudah pasti meskipun bebas dari konteks kalimatnya. Kata tersebut bermakna 'dosen yang membimbing atau membina'. Kata mata kuliah merupakan komposisi idiomatik sebagian, yaitu mata berarti satuan pelajaran sedangkan kuliah merupakan tingkat perguruan tinggi. Sehingga, mata kuliah berarti 'satuan pelajaran pada bangku kuliah atau perguruan tinggi'. Kata tunjuk ajar merupakan komposisi yang berarti 'petuah, petunjuk, nasihat, amanah, 
pengajaran, dan contoh teladan yang bermanfaat bagi mahasiswa'.

Pada data (5), terdapat kata orang tua. Komposisi orang tua terbentuk dari kata orang dan tua yang memiliki arti 'ayah dan ibu'. Data (6-9) mengandung komposisi kata terima kasih. Kata terima kasih memiliki makna 'rasa syukur yang dirasakan oleh seseorang atau membalas budi setelah menerima kebaikan'. Pada data (10), terdapat komposisi kata ilmu pengetahuan. Ilmu pengetahuan merupakan gabungan biasa yang kedua unsurnya memiliki komponen makna anggota dari salah satu dari medan makna sehingga di antara keduanya dapat disisipkan kata dan berarti 'menjadi ilmu dan pengetahuan'. Kemudian pada data (11), terdapat kata masyarakat modern yang berarti 'masyarakat yang hidup dalam modernisasi, yaitu mengikuti perkembangan zaman'.

\section{KESIMPULAN}

Penguasaan reduplikasi dan komposisi pada makalah mahasiswa Malaysia UIN Sunan Ampel Surabaya sebagai berikut. Penguasaan reduplikasi ada dua, yaitu (1) pengulangan seluruh atas bentuk dasar dan (2) pengulangan bentuk dasar dengan imbuhan. Penguasaan komposisi ada tiga, yaitu (1) komposisi yang menghasilkan istilah, (2) komposisi yang salah satu unsurnya berupa pokok kata, (3) komposisi yang unsur-unsurnya tidak mungkin dipisahkan atau tidak mungkin diubah strukturnya.

\section{UCAPAN TERIMA KASIH}

Ucapan terima kasih disampaikan kepada semua pihak yang telah membantu dalam penyelesaian penelitian ini. Adapun pihak-pihak tersebut adalah (1) Drs. Djoko Adi Walujo, S.T., M.M., DBA., selaku Rektor Univesitas PGRI Adi Buana Surabaya atas kebijakannya yang telah mendanai penelitian ini, (2) Dr. Suhari., M.Si., selaku Dekan FKIP Universitas PGRI Adi Buana Surabaya atas kebijakannya yang telah memfasilitasi sehingga penelitian ini dapat terselesaikan, (3) Dr. Sukarjati, M.Kes., selaku Ketua Lembaga Penelitian dan Pengabdian Masyarakat Universitas PGRI Adi Buana Surabaya, yang telah banyak membantu dan memberi saran serta memberi motivasi sehingga penulisan laporan penelitian inni dapat terselesaikan tepat waktu, (3) Dr. Sunu Catur Budiyono., M.Hum., selaku Kaprodi Pendidikan Bahasa dan Sastra Indonesia yang telah memberikan motivasi untuk selalu meningkatkan kemampuan meneliti, (4) Teman-teman seprofesi yang telah banyak memberikan saran dan motivasi, dan (5) Pihak-pihak yang tidak bisa saya sebutkan, yang telah membantu terselesaikannya penelitian ini sampai pada pemublikasiannya.

\section{DAFTAR PUSTAKA}

Chaer, Abdul. 2008. Morfologi Bahasa Indonesia (Pendekatan Proses). Jakarta: Rineka Cipta. . 2012. Seputar Tata Bahasa Baku Bahasa Indonesia. Jakarta: Rineka Cipta. 2013. Pembinaan Bahasa Indonesia. Jakarta: Rineka Cipta.

Keraf, Gorys. 1991. Tata Bahasa Indonesia. Ende:Nusa Indah.

Kridalaksana, H. 2007. Pembentukan Kata dalam Bahasa Indonesia. Jakarta: PT Gramedia Pustaka Utama. . 2008. Kamus Besar Bahasa Indonesia Ed. IV. Jakarta: PT Gramedia Pustaka Utama.

Moleong, Lexy J. 2001.Metodologi Penelitian Kualitatif. Bandung: PT Remaja Rosdakarya.

Muslich, Masnur. 1990. Tata Bentuk Bahasa Indonesia Kajian ke Arah Tata Bahasa Deskriptif. Malang: YA 3 Malang. 2010. Tata Bentuk Bahasa Indonesia. Jakarta: Bumi Aksara. 


\section{Bahasa Indonesia pada}

Era Globalisasi. Jakarta: Rineka Cipta.

Ramlan. 2009. Morfologi Suatu Tinjauan Deskriptif. Yogyakarta: Karyono.

Sugihastuti. 2007. Bahasa Laporan Penelitian. Yogyakarta: Pustaka Pelajar. 